\title{
Bipolar Disorder and Obsessive Compulsive Disorder Comorbidity: Three Case Reports
}

\author{
K. Semra Karataș ${ }^{1}$, Jülide Güler ${ }^{2}$, Aytül Hariri ${ }^{3}$
}

\section{ÖZET:}

iki uçlu bozukluk ve obsesif kompulsif bozukluk ekhastalıg̃ı: Üç olgu sunumu

iki uçlu bozukluk (iUB) ekhastalıg̃ı, hastalarda mizaç bozuklukları dıșındaki DSM-III-R eksen I hastalıkları ya da ciddi tıbbi hastalıkların birlikteligai olarak tarif edilmiștir. Birçok eksen I ve/veya eksen II hastalıkları iUB ile birlikte olabilir. Madde kullanımına bag̃lı bozukluklar, panik bozukluk, obsesif kompulsif bozukluk (ОKB) ve borderline kișilik bozuklug̃u en sık rastlanan bozukluklardır. IUB'de OKB yaygınlıg̃ının saptanmasına dair az sayıda çalıșma vardır. ilk olgu sunumları ve tedavi çalıșmaları OKB ve IUB'nin ekhastalık olabileceg̃ini düșündürmektedir. Biz burada OKB'nin eșlik ettig̃i üç kadın iUB hastanın belirtileri, hastalık seyirleri ve tedavilerinin karşlıklı etkileșimlerini tartışacag̃ız.

Anahtar sözcükler: iki uçlu bozukluk, obsesif kompulsif bozukluk, ekhastalık, depresyon, mani

Journal of Mood Disorders 2013;3(1):33-6

\begin{abstract}
:
Bipolar disorder and obsessive compulsive disorder comorbidity: three case reports

Comorbidity in bipolar disorder has been described as the co-occurrence of nonaffective DSM-III-R Axis I disorders or serious medical illnesses in bipolar patients. Almost all axis I and/or axis II disorders may co-occur with bipolar disorder. The most common ones are substance use disorders, panic disorder, obsessive compulsive disorder, and borderline personality disorder. Few studies estimated the prevalence of obsessive compulsive disorder (OCD) comorbidity with bipolar disorder (BD). Some case reports and treatment trials suggested that $O C D$ might be seen comorbidly in patients with $\mathrm{BD}$. Here we have reported three female cases of $\mathrm{BD}$, who have had accompaniying $O C D$ and discussed reciprocal interactions of the symptoms, illness courses, and treatments of both conditions.
\end{abstract}

Key words: bipolar disorder, obsessive-compulsive disorder, comorbidity, depression, mania

Journal of Mood Disorders 2013;3(1):33-6
${ }^{1}$ Department of Psychiatry, Rize State Hospital, Rize-Turkey 2Department of Psychiatry Erenkoy Psychiatry Disorder and Research Hospital,

Istanbul-Turkey

${ }^{3}$ Department of Psychiatry, Istanbul Maltepe University, Faculty of Medicine, Istanbul-Türkiye

Yazıșma Adresi / Address reprint requests to: K.Semra Karataș, Recep Tayyip Erdog̃an Üniversitesi TIp Fakültesi, islampaşa Mahalles 53100 Merkez, Rize-Turkey

Telefon / Phone: +90-464-212-3009/12

Elektronik posta adresi / E-mail address: drsemraocak@yahoo.com

Kabul tarihi / Date of acceptance: 18 Aralık 2012 / December 18, 2012

Bag̃ıntı beyanı:

K.S.K., J.G., A.H.: Yazarlar bu makale ile ilgil olarak herhangi bir čkar çatıssması

bildirmemiştir.

\section{Declaration of interest:}

K.S.K., J.G., A.H.: The authors reported no conflict of interest related to this article.

\section{INTRODUCTION}

Comorbidity is known to occur in various psychiatric disorders. There is comorbidity between Bipolar Disorder (BD) and Obsessive Compulsive Disorder (OCD), but relatively few systematic data exist on the clinical characteristics of this interface and the treatment (1).

Most reports evaluated the OCD comorbidity in unipolar and bipolar mood disorders. Perugi et al. showed in a consecutive series of 315 OCD outpatients, that $15.7 \%$ presented a bipolar comorbidity, mostly with BP-II disorder. Recent studies reported that lifetime prevalence of OCD and BD comorbidity was $12.4 \%$. Further analyses suggested that when comorbidity occurs with OCD and bipolar or unipolar depression, it has a differential impact on the clinical picture and course of OCD (2). In addition, another study emphasized BD and OCD comorbidity creates difficulties in the treatment (3).
Here we report three female cases of BD who has had accompaniying OCD. We used Yale-Brown Obsessive Compulsive Scale Symptom Checklist and Structured Clinical Interview for Diagnostic and Statistical Manual of Mental Disorders, Fourth Edition-IV/Clinical Version on bipolar patients.

\section{CLINICAL REPORT}

\section{CASE 1}

She has been a 30 year-old, house wife, married, with one child. She has lived in city with her family. She has had bipolar disorder for about 10 years and obsessive thoughts for about 6 years. She became uncomfortable about her obsessive thoughts and compulsive movements during last year. She has been suffering from contamination obsessive thoughts and washing her hands by means of compulsive movements. She 
has had positive family history for BD. BD has began with a severe manic episode with psychotic features. She has had no suicide attempts. Her first medical treatment included 1000 mg valproic acid, risperidone $3 \mathrm{mg}$, chlorpromazine $100 \mathrm{mg}$ and biperiden $2 \mathrm{mg}$ per day. She has had only 3 manic attacks over 10 years. She has had no depressive attacks so far. We started clomipramine $150 \mathrm{mg} /$ day to her. She has taken clomipramine for 7 months and there has been nomanic shift.

\section{CASE 2}

She has been a 41 year-old, housewife, never married. She has lived in city with her family. She has had bipolar affective disorder for about 10 years and obsessive thoughts for about 20 years. She has had positive BD family history. She has became uncomfortable about her obsessive thoughts and compulsive movements over last 2 years. She has suffered from obsessions of contamination and pathological doubts along with cleaning rituals and spitting rituals. BD began with a severe manic attack with psychotic features.

She has had no suicidal attempts. Her first medication regimen included $1000 \mathrm{mg}$ valproic acid, risperidone $3 \mathrm{mg}$, biperiden $2 \mathrm{mg}$ per day. She has had 2 mixed and 2 depressive episodes so far. Her current medication regimen consists of $1250 \mathrm{mg}$ valproic acid, risperidone $3 \mathrm{mg}$, clomipramine $300 \mathrm{mg}$, biperiden $2 \mathrm{mg}$ per day. She was put on clomipramine and has continued for 18 months. There has been no manic shift so far.

\section{CASE 3}

She has been a 27 year-old, single, employed female, who has been living with her brother in the city. She has had bipolar disorder for about 11 years and developed obsessive and compulsive disorder during last year. She had obsessions of contamination and pathological doubts along with cleaning rituals. BD has began with a severe manic episode with psychotic features. She has had no suicide attempts so far. Her current medical conssits of $1000 \mathrm{mg}$ valproic acid, risperidone $2 \mathrm{mg}$, fluvoksamin $200 \mathrm{mg}$ per day. She has been on fluvoksamine for about 6 months and there has been no manic shift so far.

\section{DISCUSSION}

OCD is equally common in bipolar as in unipolar patients
(4). Bipolar OCD subjects have characterized by episodic course of OCD, more positive family history for mood disorders, and high rates of comorbidity with depression, social phobia, or generalized anxiety disorder. They have reported to have less severe OCD and had somewhat different symptom profile compared to nonbipolar OCD. The OCD predated bipolar disorder in $54 \%$ of the bipolar OCD subjects; and in the remaining subjects, it had an onset during the course of bipolar disorder. Lifetime prevalence of OCD and BD comorbidity was $12.4-15.7 \%$. No cases of OCD were detected during mania. Two of our cases has developed OCD during mania $(5,6)$.

Psychobiological mechanisms that may account for these high comorbidity rates likely involve a complicated interplay among various neurotransmitter systems, particularly norepinephrine, dopamine, gamma-aminobutyric acid (GABA), and serotonin. The second messenger system constituent, inositol, may also be involved. In treatment of OCD with BD first step treatment is to use mood stabilizer and to consider cognitive behaviour terapy (CBT) first or combined with pharmacotherapy targeted to the OCD. Second step of treatment is to combine mood stabilizer with selective serotonin reuptake inhibitors (SSRI)s, third step is combining mood stabilizer with Venlafaxine, and finally in fourth step to consider trying another SSRIs, augmenting with buspirone, or adding risperidone and/or clomipramine. If the patient switches to manic episode during treatment of OCD with antidepressants or OCD persists, is debilitating, or has not responded to $\mathrm{CBT}$, one should consider adding a second or third mood stabilizer before a retrial of an SSRI $(8,9)$.

Little controlled data are available regarding the treatment of bipolar disorder complicated by OCD. OCD generally require long-term treatment with antiobsessional agents include SSRIs. However, adequate mood stabilization should be achieved before antidepresants are used to treat residual anxiety symptoms in order to minimize antidepressantinduced mania or cycling (10). Another study emphasized that drug treatment with clomipramine and to a lesser extent, with SSRIs was associated with hypomanic switches in OCD-bipolar patients, especially in those, who were not concomitantly treated with mood stabilizers (11).

Also the other factors associated with acute manic decompensation in BD are psychosocial stressors, lack of psychosocial support sysytem, unusual pharmacokinetics, presence of psychotic symptoms, presence of residual symptoms, comorbid medical conditions, and temperament (8). 
In a recent study emphasized that $\mathrm{BD}$ is one edge and the other edge is affective temperament (12). In affective temperament and BD association has manic shift in antidepressant effect (13). Manic switches were more frequent among bipolar patients with hyperthymic temperament. A study, which investigated the causes of manic shift showed that hyperthymic temperament had the most risk. BD clinical implication, courses, comorbid disorder investigation denote that hyperthymic group has more shift and cyclothymic group has more comorbid disorders. These findings suggest that manic shift is not only be caused with drug uses, but also with preseence of structural sides (14).

In our cases we started mood stabilizers before antidepressant treatment. We used clomipramine and fluvoxamine in our cases and we have not observed any antidepressant induced mania. Mood switching rate under anti-OCD drugs was equivalent in both OCD populations.

In recent study, $85 \%$ of patients with bipolar or major depressive disorder showed complete or partial improvement after treatment with varying doses of risperidone in terms of decreases in agitation, psychosis, sleep disturbance, and rapid cycling. All patients with refractory OCD showed significant symptomatic improvement after the addition of risperidone (15). We used risperidone for psychotic symptoms and we had observed decreases agitation and sleep disturbance.

\section{References:}

1. Perugi G, Akiskal HS, Pfanner C, Presta S, Gemignani A. The clinical impact of bipolar and unipolar affective comorbidity on obsessive compulsive disorder. J Affect Disord. 1997;46:15-23.

2. Hantouche EG, Kochman F, Demonfaucon C, Barrot I, Millet B, Lancrenon S. Bipolar obsessive-compulsive disorder: confirmation of results of the "ABC-OCD" survey in 2 populations of patient members versus non-members of an association. Encephale. 2002; 28:21-28.

3. Kalra H, Tandon R, Saluja B, Mohan I. Obsessive compulsive disorder:comorbidity in manic phase of bipolar disorder. Indiana J Psychiatry. 2002;44:377-9.

4. Gordon A, Rasmussen SA. Mood related obsessive compulsive symptoms in a patient with bipolar affective disorder. J Clin Psychiatry. 1988;49:27-8.

5. Krüger S, Cooke RG, Hasey GM, Jorna T, Persad E. Comorbidity of obsessive compulsive disorder in bipolar disorder. J Affect Disord. 1995;34:117-20.

6. Chen YW, Dilsaver SC. Comorbidity for obsessive-compulsive disorder in bipolar and unipolar disorders. Psychiatry Res. 1995;59:57-64.
Bipolar OCD patients had a significantly higher rate of sexual and religious obsessions and a significantly lower rate of checking rituals $(15,16)$. In our cases, patients had obsessions of contamination and pathological doubts along with cleaning rituals and spitting rituals. OCD-bipolar patients showed a more episodic course with a greater number of concurrent major depressive episodes $(17,18)$. One of our cases had no depressive episode, one of them had mixed and manic episodes, and the other one had manic and depressive episodes. There were no statistically significant differences between BD-OCD and BD without OCD groups in terms of age, sex, education, marital status, polarity, age of BD onset, presence of psychotic symptoms, presence of rapid cycling, history of suicide attempts, first episode type, and predominant episode type (19). We observed our cases had psychotic symptoms, first episode type was mania, they had no suicide attempts.

Bipolar disorder patients with obsessive-compulsive comorbidity have a number of indicators of an overall more severe illness. The presence of more anxiety symptoms and a lower social quality of life may be more specific features of the bipolar-OCD comorbidity (20).

Future studies that examine the relationship between OCD and BD using a longitudinal design may be helpful in improving our understanding of the mechanisms of this association and treatment.

7. Frederick M J. Risperidone in the treatment of affective illness and obsessive-compulsive disorder. J Clin Psychiatry. 1995;56:423-9.

8. Lakshmi N, Yatham, Stanley P, Kutcher, Vivek Kusumakar. Bipolar Disorder: A clinician's guide to treatment management. Bipolar disorder and comorbid axis I disorders: diagnosis and management. Zarate CA, Tohen MF (Eds), New York, 2002, 115-39.

9. Otto MW, Smits JAJ, Reese HE. Combined psychotherapy and pharmacotherapy for mood and anxiety disorders in adults: review and analysis. Focus. 2006;4:204-14.

10. Freeman MP, Freeman SA, McELroy SL. The comorbidity of bipolar and anxiety disorders: prevalence, psychobiology, and treatment issues. J Affect Disord. 2002;68:1-23.

11. Perugi G, Toni C, Frare F, Travierso MC, Hantouche E, Akiskal HS. Obsessive-compulsivebipolar comorbidity: a systematic exploration of clinical features and treatment outcome. J Clin Psychiatry. 2002;63:1129-34.

12. Kelsoe JR. Arguments for the genetic basis of the bipolar spectrum. J Affect Disord. 2003;73:183-97. 
13. Akiskal HS. The temperamental foundations of affective disorders Interpersonal origin and course of affective disorders. Mund $\mathrm{C}$ ve ark. (Ed), London, Gaskell, Royal College of Psychiatrists, 1996, 3-30.

14. Kesebir S, Vahip S, Akdeniz F, Yuncu Z. Bipolar bozuklukta mizaç ile klinik özelliklerin ilişkisi. Türk Psikiyatri Dergisi. 2005;16:164169.

15. Zutshi A, Kamath P, Reddy YC. Bipolar and nonbipolar obsessive compulsive disorder: a clinical exploration. Compr Psychiatry. 2007;48:245-51

16. Magalhaes PV, Kapczinski NS, Kapczinski F. Correlates and impact of obsessive-compulsive comorbidity in bipolar disorder. Compr Psychiatry. 2010;51:353-6.
17. Maina G, Albert U, Pessina E, Bogetto F. Bipolar obsessivecompulsive disorder and personality disorders. Bipolar Disord. 2007;9:722-9.

18. Pashinian A, Faragian S, Levi A, Yeghiyan M, Gasparyan K,Weizman R. Obsessive compulsive disorder in bipolar disorder patients with first manic episode. J Affect Disord. 2006;94:151-6.

19. Koyuncu A, Tükel R, Ozyildirim I, Meteris H, Yazici O. Impact of obsessive-compulsive disorder comorbidity on the sociodemographic and clinical features of patients with bipolar disorder. Compr Psychiatry. 2010;51:293-7.

20. Presta S, Marazziti D, Dell Osso L, Pfanner C, Pfanner P. Obsessive-compulsive disorder in childhood and adolescence. Psychopathology. 2003;36:55-64. 